\title{
Correlation of precipitation distribution and quality sweet cherry production
}

\author{
Szenteleki, K. ${ }^{1}$, Gaál, M. ${ }^{1}$, Mézes, Z. ${ }^{2}$, Soltész, M. ${ }^{2}$, Nyéki, J. ${ }^{2}$ \& Szabó, Z. ${ }^{2}$ \\ ${ }^{1}$ Corvinus University of Budapest, Hungary \\ ${ }^{2}$ University of Debrecen, Hungary
}

\begin{abstract}
Summary: Sweet and sour cherry need $550-600 \mathrm{~mm}$ yearly precipitation. The critical period is $1-1.5$ month after flowering, it is normally between 15. April - 15. June in Hungary. The rain induced fruit cracking is also a critical and costly problem for cherry growers. Fruits grown under arid conditions are less resistant against rainfall during harvest and up to 50-60\% crack damage may occur. A computer program was developed to calculate the precipitation related production risks of sweet cherry. Focus of the research was Zala county. Spatial distribution of precipitation was compared in two directions (East and North of Zala county) based on the data of meteorological stations. The first results indicate that the developed method estimates the risks quite well, compared to the farm experiment results. The developed computer program can be parameterised according to the user's requirements, this allows to take into account the real variety structure of a given orchard.
\end{abstract}

Key words: sweet cherry, fruit cracking, fruit quality

\section{Introduction}

Beside minimum annual water demand the yearly temporal and spatial distribution of rainfall is essential for fruit development. There are two important factors of sweet cherry production:

- Rainfall between blooming and harvest should be well balanced, a weekly $10-15 \mathrm{~mm}$ of rain ensures optimal fruit weight increase. Constant rain distribution in the above mentioned period on the other hand gives a good condition for the fruits and reduces the effect of rainfall in the harvest period (crack damage of fruits and development of fungi). Damaged fruits can be hardly sold on the market which means financial loss for the producer (Nyéki et al., 1997; Papp, 2004).

- The second factor is in connection with the 10-15 days period before harvest. If there is significant rainfall during, the fruit crack damage appears. Reason is osmotic concentration difference of the liquid of the fruit inside and the rain water on the surface of the crop. If more than $50 \%$ of the crop has crack damage than the product can be sold only for juice production industry for a much lower than fresh market price (Sekse, 1998).

\section{Materials and methods}

With appropriate meteorological data for fifty to hundred years we can analyze if these requirements for quality fruit production occurred at the past. The volume and distribution of rainfall was partly fulfilled the above mentioned factors in the past but never fully satisfied the criteria of cherry fruit. Every year a risk factor can be calculated based on the historical meteorological data. Permanent and well balanced precipitation can be easily monitored by computer software in any time period during the last 100 years (Erdélyi et al., 2006). Criterion could be the number of weeks when 10-15 $\mathrm{mm}$ rain occurred or not. In this research we calculated the number of weeks during the investigated season when there was the appropriate precipitation amount. The investigated period was with variable length - as the ripening times are different - between 15. April and the beginning of harvest. We put the harvest time between 25. May and 10. July including early, mid and late harvest sweet cherry varieties. Average water supply indicators for different growing periods have been calculated for every year. Result is the K1 risk factor, which shows the being of permanent and well balanced precipitation between April and June (Ladányi, 2008; Erdélyi, 2006).

Harvest period was marked between 20. May and 10 . July, namely the $145^{\text {th }}$ and $191^{\text {st }}$ day of the year. Four risk factors were calculated for every harvest day according to the following algorithm:

- K2 risk factor: 10-6. days before harvest at least $15 \mathrm{~mm}$ rain occur $1 \mathrm{x}=0.15 ; 2 \mathrm{x}=0.4 ; 3 \mathrm{x}=0.7$

- K3 risk factor: 5-1. days before harvest at least $10 \mathrm{~mm}$ rain occur $1 \mathrm{x}=0.2 ; 2 \mathrm{x}=0.5 ; 3 \mathrm{x}=0.8$

- K4 risk factor: during harvest at least $5 \mathrm{~mm}$ rain occur $1 \mathrm{x}=0.8 ; 2 \mathrm{x}=1$

The overall risk factor is like follows:

- $\mathrm{K} 2+\mathrm{K} 3+\mathrm{K} 4=\mathrm{K} 5$; if $\mathrm{K} 5>1$, than $\mathrm{K} 5=1$.

The developed computer program can be parameterised according to the user's requirements. The necessary calculations for any year or time period such as decade, 
century and etc. can be calculated fast and exactly with this software. The software is able to make a separation by growing period of the different varieties such as early, mid and late harvest sweet cherries. The risk factors can be estimated in a weekly basis for the whole harvest period for decades in the past.
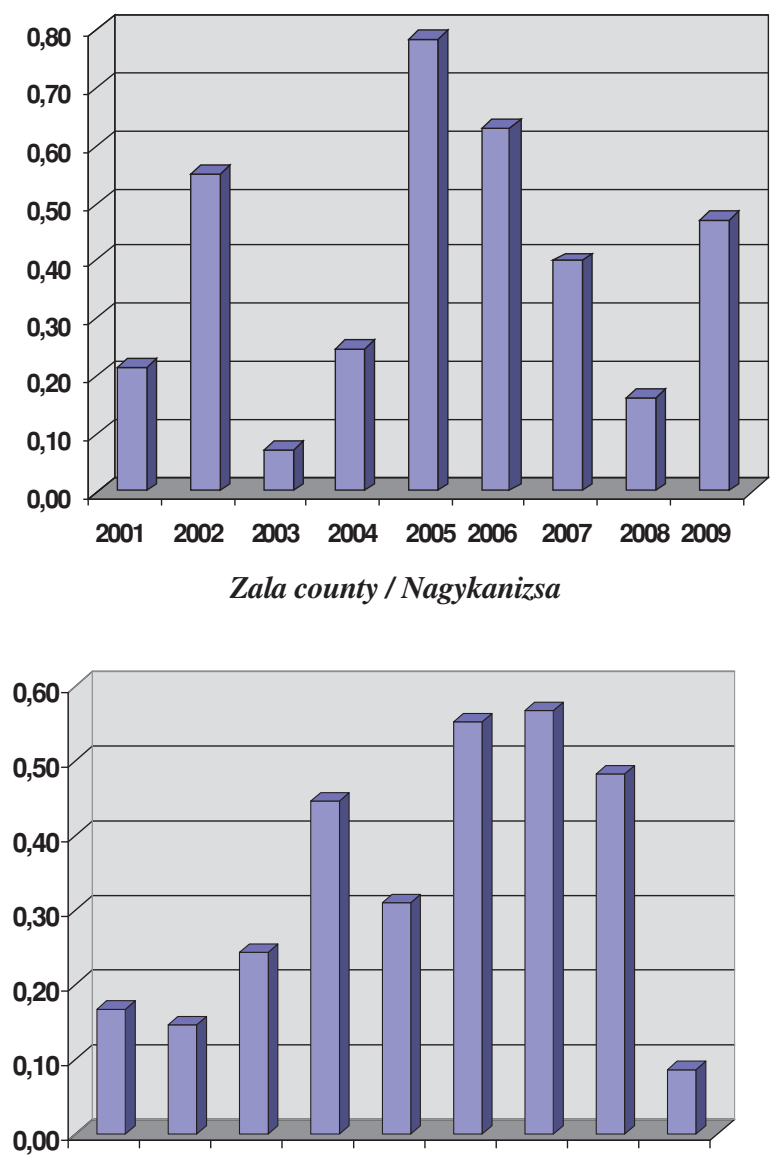

200120022003200420052006200720082009

Györ county / Györ

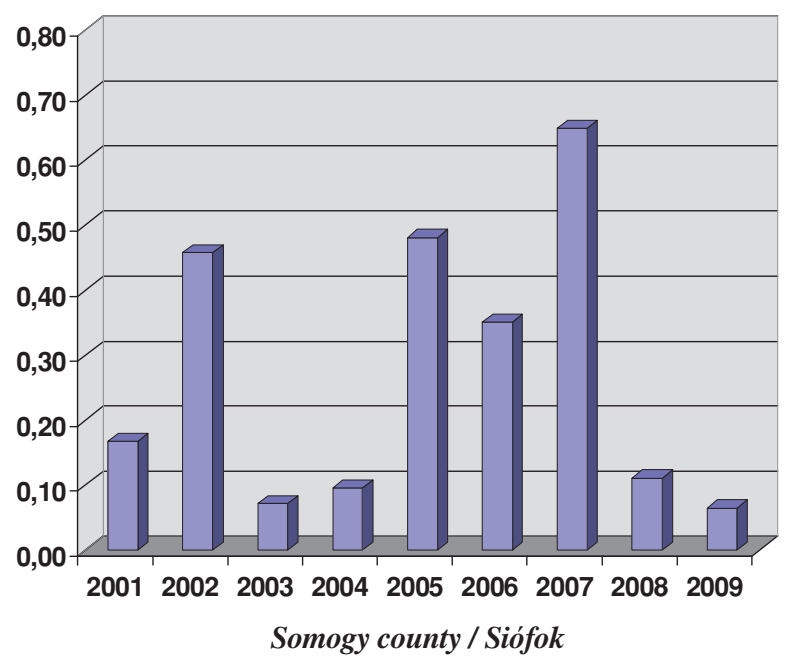

Figure 1. Water supply of sweet cherry during the growing period (K1)
Meteorological data were provided by OMSZ (Hungarian Meteorological Service) partly from public communications, internet sites and from official data by contracting with OMSZ Éghajlati Osztály (Hungarian Meteorological Service - Climate Department). Data for the precipitation map - baseline period, 1961-90 - were obtained from the CRU CL 2.0 database (New et al., 2002), which has 10' grid spatial resolution.
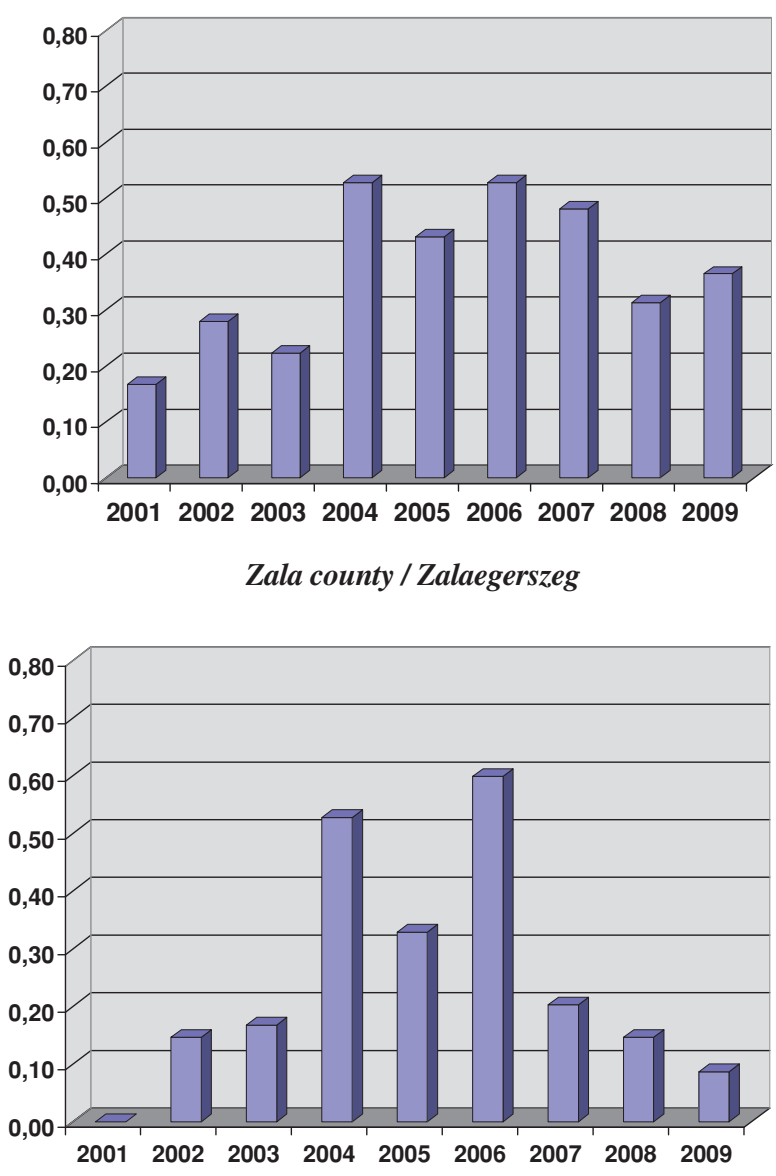

Veszprém county / Pápa

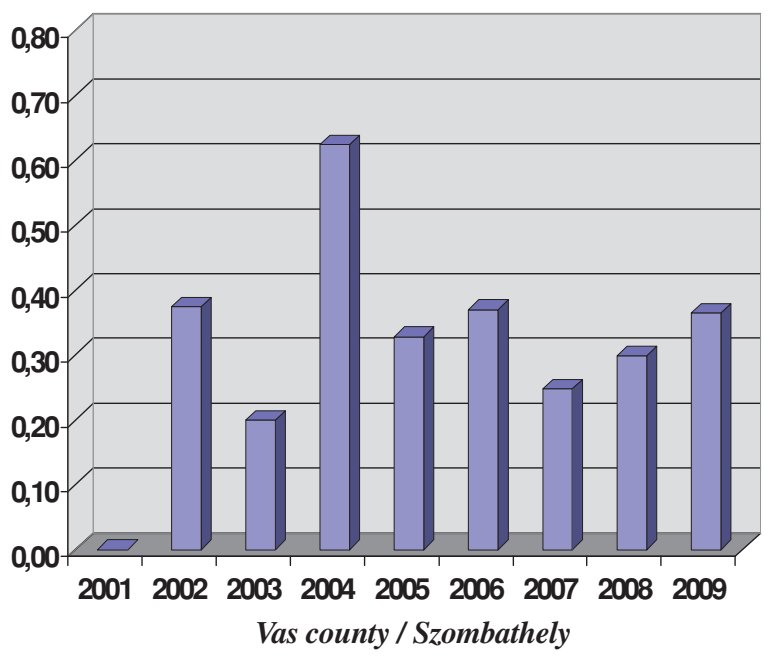




\section{Results}

\section{Rainfall with positive effect on sweet cherry quality}

Research has been made in four West-Hungarian counties (Győr-Moson-Sopron, Vas, Zala and Somogy) including five weather stations. In the first step the cumulated weekly precipitation was calculated from 15 . April to every harvest day. We made a weekly analysis according to the minimal criterion of 10-15 mm rainfall and the average of these frequency values were calculated for the whole period. Satisfaction rate of this criterion is shown in Figure 1.

According to the graphs natural water supply of cherry is uncertain during the period between flowering and harvest but obviously the best in Zala county. The research has been made for long time scale -50 years for all the country but 100 years for the centre region and Great Hungarian Plain. Situation is more critical in Győr-Moson-Sopron county and Vas county but the worst is in Somogy county (Siófok) and this is perhaps the reason why the modern orchards can be made only with irrigation system in this area (Bartholy J. et al. 2009).

Our results are not surprising if we make the precipitation map of Hungary during April - June (Figure 2.).

Calculation and representation of the well balanced precipitation index gives a good opportunity to compare different production areas. The centre of the comparison was

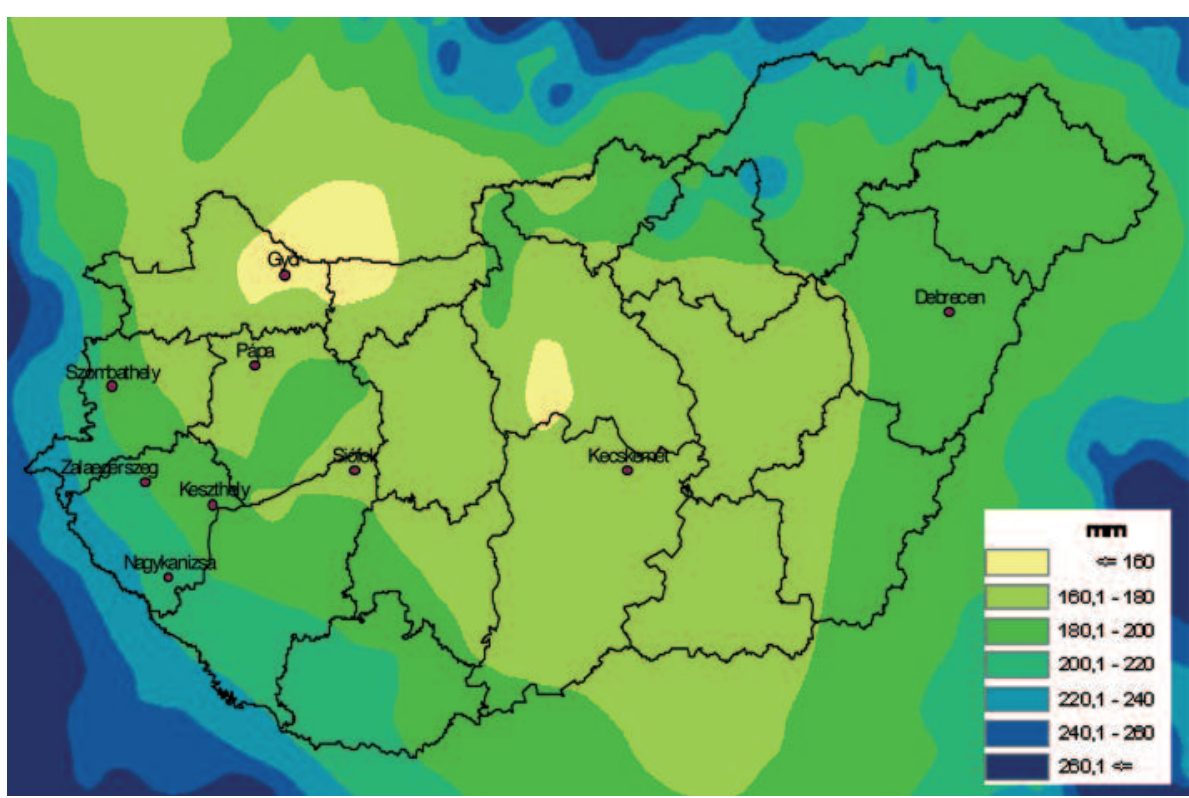

Figure 2. Precipitation during April - June, 1961-1990 (source: CRU database)
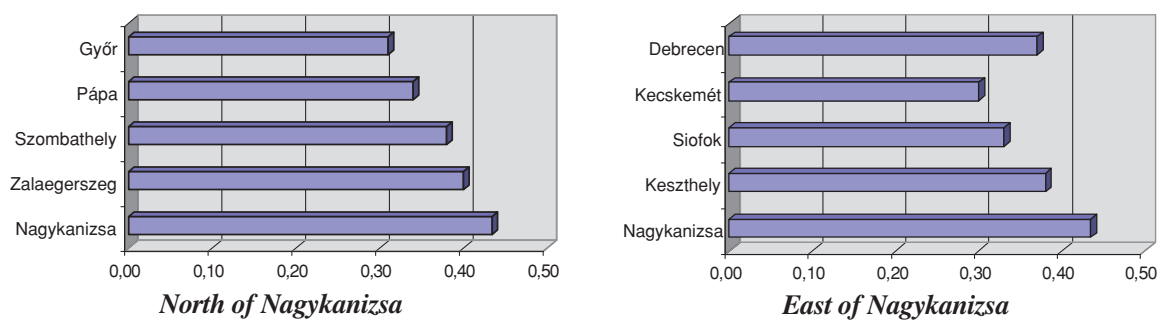

Figure 3. The well balanced precipitation indexes across the country, 1951-2009
Nagykanizsa, from it two groups have been created according to the geographical position (1. north of Nagykanizsa; 2. east of Nagykanizsa). We have a time scale for almost 60 years in the past and according to the calculations Nagykanizsa has the best precipitation index for sweet cherry. In the north direction can be seen that the precipitation index has lower value by the distance from Nagykanizsa (Figure 3).

The reason of the second direction (east-west) is to show the differences across the country. Base is Nagykanizsa like before and the border point is Újfehértó (Debrecen area). The well balanced precipitation index is going down as the distance is higher from Nagykanizsa, in the middle of the country (Kecskemét) has the smallest value, but until the eastern border the index value is raising again. A remarkable result is that the precipitation index of Györ area is almost the same like the value of mid Hungarian cities (Kecskemét area). The precipitation map (Figure 2) shows the same result but it should be emphasized that the precipitation index is a better standard than the precipitation sum of a given period (Soltész et al., 1999; Thurzó et al., 2007).

\section{Rainfall with negative effect on sweet cherry quality}

During ripening and harvest period rainfall can be a hazard for the fruit quality. If the water supply of this period is too high cracking damage occur, which disables the selling on fresh market as a first class fruit. In some extreme years the cracking damage can be up to $80-100 \%$ making the harvest less productive (Christiensen, 1996; Csiszár, 2004). Some experiments showed a good result of spraying with pesticides containing Ca (Simon, 2006; Simon et al., 2007). On the other hand the schedule of the harvest has an effect on fruit quality, because right after rain harvesting is not recommended as the crack damage occurs in the compartments with fungi on the top of the fruit (Demirsoy et al., 1998; Simon et al., 2008). If harvest is done by machine than we recommend a 1-2 days brake after a significant rainfall otherwise fruits falling down on the receiving hood could have $30-40 \%$ more cracking than a few days later (Soltész et al., 2006; Simon, 2003).

According to the introduction of the article the precipitation risk during harvest period was calculated on a daily basis but is more transparent to publish on weekly terms for the period last week of May - 10. July. Cracking damage has a more direct and exact effect on fruit quality than the precipitation evenness during spring. 


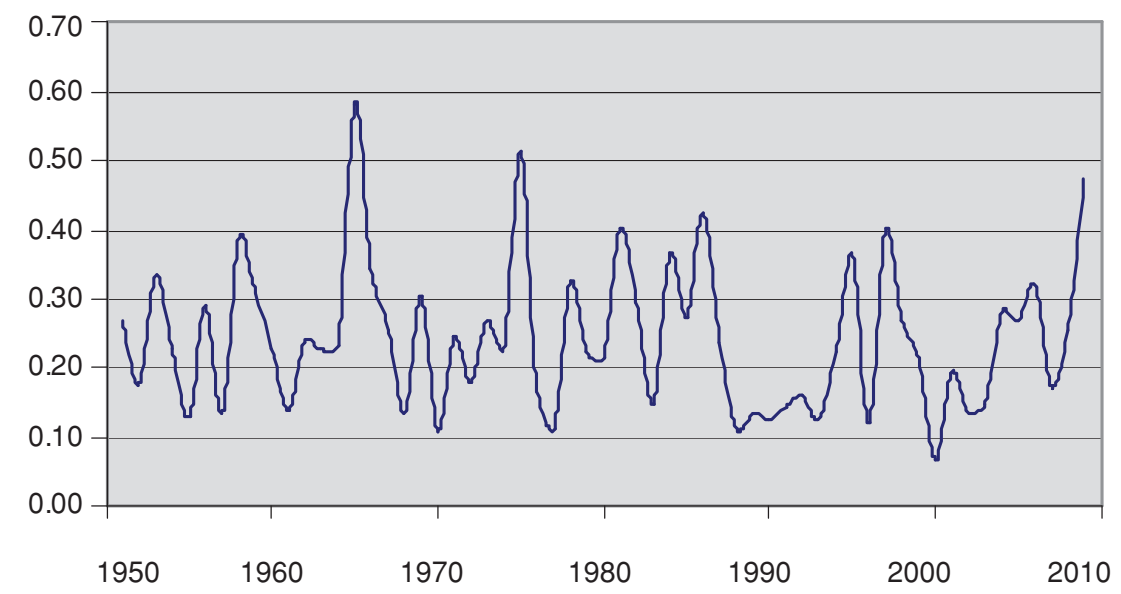

Figure 4. Risk of fruit cracking damage in Nagykanizsa, 1951-2009

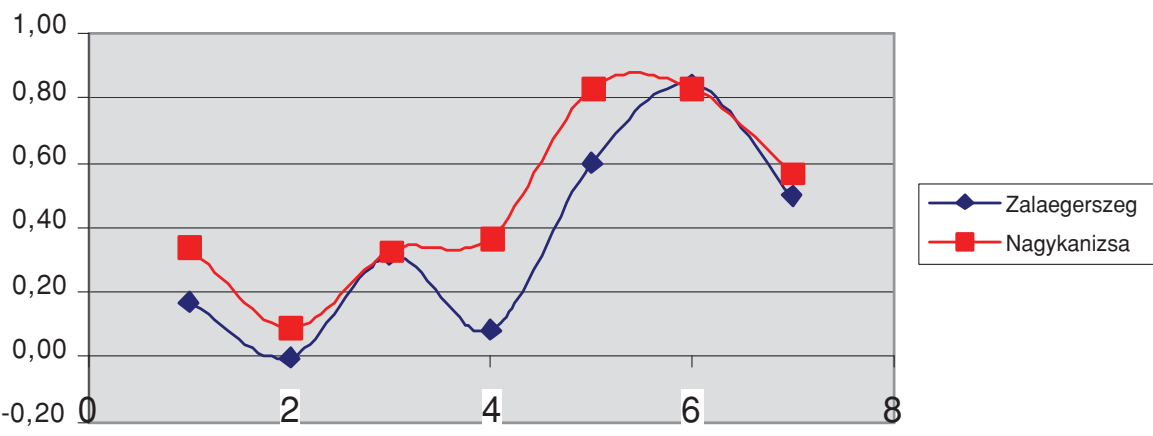

Figure 5. Risk of fruit crack damage by the week of harvest period (25. May - 10. July)

Amount of precipitation in the harvest period directly affects the percentage of rain induced fruit cracking.

The developed risk factor of fruit crack damage has an average value between 10-40\% except some years with extreme weather. Such a year was 2009 when our risk estimation in Nagykanizsa gave a result of $48 \%$ of crack damage. A farm in Nagykutas (Zala county) made a detailed statistic of the rain induced fruit cracking damages, given in Table 1.

Average fruit cracking damage of the 13 varieties was $42 \%$. There are two weather stations in the surroundings of the Nagykutas farm: Nagykanizsa and Zalaegerszeg. The fruit cracking risk was calculated for both weather stations. The obtained results for the year 2009 are presented in Figure 5. Based on the data from Zalaegerszeg we got $36 \%$ for risk of fruit

Table 1. Fruit cracking of sweet cherry varieties, Nagykutas (Source: consortium report 2009)

\begin{tabular}{|l|c|c|c|}
\hline Variety & $\begin{array}{c}\text { Ratio of } \\
\text { cracked fruits }\end{array}$ & Variety & $\begin{array}{c}\text { Ratio of } \\
\text { cracked fruits }\end{array}$ \\
\hline Techlovom & $76 \%$ & Giant Red & $40 \%$ \\
\hline Sanda Ross & $61 \%$ & Regina & $39 \%$ \\
\hline Canada Giant & $54 \%$ & Cristalina & $37 \%$ \\
\hline Katalin & $45 \%$ & Skeena & $34 \%$ \\
\hline Alex & $44 \%$ & Symphony & $29 \%$ \\
\hline Sweetheart & $44 \%$ & Germersdorfi Riple & $19 \%$ \\
\hline & & Chelon & $18 \%$ \\
\hline
\end{tabular}

\section{References}

damage. The farm is near to these weather stations so our estimation gave proper result compared to the field experiment. Our computer software is able to handle varieties with different ripening time. In the above mentioned estimation we did not use this parameter in the software but if there is a concrete farm with certain variety structure the model can be more exact. For example the graph below shows the detailed calculation of the expected fruit crack damage every week between 25. May - 10. July.

Figure 5. shows that the risk level of cracking damage in Zalaegerszeg was lower in each and every week of the harvest period than in Nagykanizsa. Long-term calculations based on 60 years historical data gave the same result, there is approximately 5\% difference in the risk level of the two stations. Of course there is a probability of change because every year is different but the aim of long term historical data analysis is to get a realistic risk assessment of the fruit production in an area. It is recommended to make these calculations for example before planting a new orchard to choose between early, mid and late varieties also based on the risk level of the future production.

Bartholy, J., Pongracz, R., Torma, Cs., Pieczka, I., Kardos, P. \& Hunyady, A. (2009): Analysis of regional climate change modelling experiments for the Carpathian basin. International Journal of Global Warming, 1 (1-2-3.): 238-252.

Christiensen, J.V. (1996): Rain-induced cracking of sweet cherries: it causes and preventation. In: Webster, A. D., Looney, N.E. (eds.): Cherries: Crop physiology. Production and uses. CAB International, 297-327. pp.

Csiszár, L. (2004): A cseresznye repedésének mechanizmusa és az azt befolyásoló egyes tényezők. (In: Inántsy F., Balázs K. (szerk.): Integrált növénytermesztés. Meggy, cseresznye.) Agroinform Kiadó, Budapest, 200-205. pp.

Demirsoy, L.K. \& Bilgener, S. (1998): The effects of preharvest chemical applications on cracking and fruit quality in 0900 'Ziraat', 'Lambert' and 'Van' sweet cherry varieties. Acta Hort., 468: 663-670

Erdélyi, É., Horváth, L., Boksai, D. \& Ferenczy, A., (2006): How climate change influences the field crop production ECOConference (Novi Sad), 7-12. pp.

Erdélyi, É. (2006): Graph theory application for investigating agroecosystems effected by extrem weather conditions - Applied Ecology and Environmental Research, 4(2): 181-187.

Ladányi, M. (2008): Risk methods and their applications in agriculture - a Hungarian approach - Applied Ecology and Environmental Research, 6 (1): 147-164. 
New, M., Lister, D., Hulme, M. \& Makin, I. (2002): A highresolution data set of surface climate over global land areas. Climate Research, 21: 1-25.

Nyéki J., Soltész, M. \& Szabó, Z. (1997): A gyümölcsminőség tényezői a csonthéjasok integrált termesztésében. "Agro-21" Füzetek 15: 57-71.

Papp, J. (2004): A gyümölcsök termesztése 2. Mezőgazda Kiadó

Sekse, L. (1998): Fruit cracking mechanism in sweet cherries (Prunus avium L.) - a review. Acta Hort., 468: 637-648.

Simon, G. (2003): Az ültetvények védelme az eső és a madarak által okozott károk ellen. (In Hrotkó K. (szerk.) 2003: Cseresznye és meggy.) Mezőgazda Kiadó Budapest, 338-345.

Simon, G. (2006): Review on rain induced fruit cracking of sweet cherries (Prunus avium L.), its causes and the possibilities of prevention. International Journal of Horticultural Science 12 (3): 27-35.

Simon, G., Tóth, M. \& Papp, J. (2007): Cracking susceptibility of sour cherry (Prunus cerasus L.) in Hungary and relation to calcium application. International Journal of Horticultural Science 2007, 13 (3): 109-118.
Simon, G., Tóth, M. \& Papp, J. (2008): A fajták gyümölcsepedési hajlamának vizsgálata szabadföldön és laboratóriumban, gyümölcsrepedést gátló készítmények alkalmazási technológiájának kidolgozása c. zárójelentés a meggy 006 sz. GAK kísérletekhez

Soltész, M., Nyéki, J., Kovács, J., Dibuz, E. \& Szabó, Z. (1999): Agroclimatological properties of growing sites assigned to apple and pear production in Hungary. International Journal of Horticultural Science, 5 (3-4): 95-97.

Soltész, M., Nyéki, J., Szabó, Z., Lakatos, L., Racskó, J., Holb. \& Thurzó S. (2006): A cseresznye és meggy repedése és az ellene való védekezés (In: Csete L., Nyéki J. (szerk.) Klímaváltozás és a magyarországi kertgazdaság) Agro-21 Kiadó. Budapest, 84-92. pp.

Thurzó, S., Balmer, M., Hilsendegen, P., Silva, A.P. Goncalves, B. \& Simon, G. (2007): Platzempfindlichkeit von Süß- und Sauerkirschsorten an verschiedenen Standorten in Deutschland, Portugal und Ungarn. 44. Gartenbauwissenschaftliche Tagung, Erfurt. Kurzfassungen der Vortrage und Poster. 59. 